\title{
dossier LITERARY JOURNALISM, TRANSDISCIPLINARITY AND COMPLEXITY FIELD: \\ the journalistic and literary knowledges of João Guimarães Rosa
}

Copyright (c) 2018 SBPjor / Associação Brasileira de Pesquisadores em Jornalismo

\section{GUSTAVO DE CASTRO}

Universidade de Brasília, Brasília - Federal District - Brazil

ORCID: https://orcid.org/0000-0001-7126-6947

FLORENCE DRAVET

Universidade Católica de Brasília, Brasília - Federal District - Brazil https://orcid.org/0000-0002-3822-3627

ANDREA JUBÉ VIANA

Universidade de Brasília, Brasília - Federal District - Brazil

https://orcid.org/0000-0003-0987-2502

VICTOR CRUZEIRO

Universidade de Brasilia, Brasília - Federal District - Brazil

https://orcid.org/0000-0003-2417-6441

DOI: 10.25200/BJR.v14n3.2018.1109

\begin{abstract}
This article seeks to situate Literary Journalism as a discipline of complex and transdisciplinary knowledge, necessary for the training of every journalist. It seeks to understand and integrate the practice of narration to the problems of the levels of reality. The concepts of Literature of Complexity and Transdisciplinarity serve as a basis for our reflection. With the short story "Com o vaqueiro Mariano", we bring the literature of João Guimarães Rosa and his relations with journalistic knowledge, from the notion of interview, through the system of production and circulation of information to the techniques of verification that the author used. Finally, we conclude that Literary Journalism allows not only to situate journalism in the communication circuit, but also, and in an extended way, broaden the communication circuit to its cultural dimension, exercising such a pedagogical role relevant to any area of knowledge.

Key words: Literary Journalism. Complexity. Transdisciplinarity. Education. Communication.
\end{abstract}




\title{
JORNALISMO LITERÁRIO, TRANSDISCIPLINARIDADE E CAMPO \\ DE COMPLEXIDADE: os saberes jornalístico-literários de João Guimarães Rosa
}

\begin{abstract}
RESUMO - Este artigo busca situar o jornalismo literário enquanto disciplina de saberes complexos e transdisciplinares, necessária à formação de todo jornalista. Busca entender e integrar a prática da narração aos problemas dos níveis de realidade. Os conceitos de literatura de complexidade e de transdisciplinaridade servem de base à nossa reflexão. Com o conto "Com o vaqueiro Mariano", trazemos a literatura de João Guimarães Rosa e suas relações com os saberes jornalísticos, desde a noção de entrevista, passando pelo sistema de produção e circulação da informação até as técnicas de apuração que o autor empregava. Por fim, concluímos que o jornalismo literário permite não só situar o jornalismo no circuito da comunicação, mas também, e de forma ampliada, estender o circuito da comunicação à sua dimensão cultural, em seu papel pedagógico relevante para qualquer área do conhecimento.

Palavras chave: Jornalismo literário. Complexidade. Transdisciplinaridade. Educação. Comunicação.
\end{abstract}

\section{PERIODISMO LITERARIO, TRANSDISCIPLINARIEDAD Y CAMPO DE COMPLEJIDAD: los saberes periodístico-literarios de João Guimarães Rosa}

RESUMEN - Este artículo busca situar el periodismo literario como disciplina de saberes complejos y transdisciplinarios, necesaria para la formación de todo periodista. Se trata de entender y de integrar la práctica de narrar los problemas de los niveles de realidad. Los conceptos de literatura de complejidad y de transdisciplinariedad sirven de base a nuestra reflexión. Con el conto "Com o vaqueiro Mariano", traemos la literatura de João Guimarães Rosa y sus relaciones con los saberes periodísticos, desde la noción de entrevista, pasando por el sistema de producción y circulación de la información hasta las técnicas de escrutinio que el autor empleaba. Por último, concluimos que el periodismo literario permite no sólo situar el periodismo en el circuito de la comunicación, sino también, y de forma ampliada, extender el circuito de la comunicación a su dimensión cultural, ejerciendo tal disciplina un papel pedagógico relevante para cualquier área del saber.

Palabras clave: Periodismo literario. Complejidad. Transdisciplinariedad. Educación. Comunicación.

\section{Introduction}

This article seeks to think the relation between Journalism and Literature, under the light of disciplinary and transdisciplinary knowledge, which, in its turn, does not pursue to gamble or invest in a specific type of journalism, nor in a new fragmentation of this already hyper-shredded and problematical field of human 
knowledge. This article therefore intends to invest in the idea of Literary Journalism as a transdisciplinary field, or a narrative capable of spreading through courses, disciplines, and university chairs in the areas of Social and Human Sciences, as well as in sections of journalism, being seen as a resource mostly in favor of the reader and the development of the human being.

What we here call Literary Journalism is not, however, a supplementation ', section or tabloid where the reader can find tales, children stories, chronicles, novellas (though it is not a bad idea, it is not the topic in this case), nor a unifying or revolutionary discourse which seeks to implode a consolidated style to edify a new one in its place. What we call Literary Journalism is the conjunction of knowledge, know-how, savoir-faire, techniques and narrative styles developed by literature that may (and should) be in service of informational and human knowledge, as well as in service of journalistic production routines. Literary journalism is, therefore, journalism in context with the various fields of human knowledge. It is, hence, a specific type of journalistic making which does not exclude any methodological or narrative resource: dialogues, profiles, tales, cordel literature, interviews, poetry, back and forth, chronicles, conventional informative articles, first person reports, notes, letters, essays, articles, fragments; everything or almost everything is permitted as long as talent, ingenuity and good sense are employed. It is exactly because it is free, challenging and risky when manipulated that Literary Journalism was little understood and explored as a transdisciplinary field, insomuch as it can be viewed more as a styling anarchy than in its complex and systemic aspect.

There is, undoubtedly, a disinterest by Communication Schools regarding the study and practice of literature. It is pertinent to inquire if Journalism, from the curricular point of view, is really moving in the right direction when not investing in, for example, narration techniques present in the interior of the literary fields. Is there any doubt that such techniques could enhance, illustrate and strengthen the journalistic text? We believe that this question should be motive for reflection: What harm could there be in bringing Journalism closer to Literature?

Trying to investigate this issue, we will pose a reflection in three stages. At first, after introducing the Brazilian thought and its dialogues to foreign thinkers on what Literary Journalism is about, we 
will show how, in our perspective, this Journalism may be conceived as a complex and systemic reality which comprises various skills and rationalities, composing a type of "sensible reason" (Maffesoli, 1998); a reality which we will call Literature of Complexity. Secondly, we will try to perceive how Literary Journalism, while a discipline, might also present itself in a transdisciplinary perspective as a favorable field to the formation of the human being and students of diverse areas of knowledge, crossing frontiers and contributing to an amplified mediatic knowledge, in which levels of reality can communicate. Last, we will show how writer João Guimarães Rosa included Journalism into the Communication circuit, which also includes Literature, establishing interdisciplinary relations among both through his stories published in literary supplements. Rosa's practice constituted an amalgam of interdisciplinary knowledge, in an ample perspective, in which Journalism, Literature and Literary Journalism present life narratives in different formats, which not only inform and charm readers, but also contribute to the growth of the reader/receptor.

\section{Literary Journalism as a Literature of Complexity}

It is not our intention here to review a literature which encompasses various conceptions and problematic involved in the thematic of Literary Journalism in Brazil and abroad. Important studies have already tackled this objective (Soares, 2017; Bak, 2017). It is our job to mention those which come closest to de dialogue we want to carry out through the transdisciplinary and complex approach.

As is shown by the Literary Journalism researcher John Bak, there is a rich production quota of international Literary Journalism, "From China to Brazil, Scotland to Australia, and Finland to New Zealand" (Bak, 2017, p. 136). In his global search for definitions, aesthetics, practices, taxonomies, records, criticisms and savoir-faire, his studies incite us to reinforce the necessity of a transdisciplinary international investment of the thoughts and practices, which are, as defended here, in the order of complexity. The comparative studies made by Bak allow us to particularly notice "the many truths" (Bak, 2017 , p. 140), the blend of traditions, the "transnational influences", which reinforce our perception that these "many truth" are causes or consequences, in the same manner, of the perception of realities which are also multiple and complex. 
For Martinez (2017), nobody up to now was more fortuitous than the American researcher John C. Hartsock when he stated that there is no consensus between scholars and practitioners about the best nomenclature to define narrative journalism. "Without the intent of definitely solving the issue, he says he decided to opt for the term Literary Journalism due to the comprehension that the texts being considered are narrative" (Martinez, 2017, p. 35).

In our opinion, Hartsock (2016) places Literary Journalism in the most ample histories of the American "objective" journalism and standard novel. For him, Literary Journalism implies an aesthetic of the experience, as much as by the one who constructs the narrative as well as by the reader, who savors a text impregnated with perceptions and experiences. Hartsock intends to bring down the myths supported by conventional journalism and wants to discuss the space occupied by Literary Journalism in an era of digital speed in which readers change media ever so quickly.

In turn and from the point of view of social research, Soares (2017) shows that the Literary Journalism, since its early days, not only contributed to expose the various urban problems of the United States as well as explored the techniques and instruments of sociological and ethnographic research, such as "interviews, engaged observation, social research, case studies" (Soares, 2017 , p. 79).

The intersection of Literary Journalism and social research, in Soares' view, reveals that the twentieth century witnessed the approximation of narrative with ethnography and the experiences in the urban context, as was with the scientific work of the sociologists. The fields of narrative and sociology cross in an interstice which contemplates research methods and interests

Literary Journalism was also defined by Lima (s.d.), in a text for the ABJL site (Associação Brasileira do Jornalismo Literário), as being the same as Literature of Reality, but it surpasses this nomenclature because it is the very notion of reality and description of reality that are at play here. It may be that there is nothing harder to define than reality. The ones who try are almost always certain to fail and, for this reason, we prefer a concept that interlaces philosophy and poetry, and that unveils reality as being "that which reveals itself to men" (Juarroz, 2000). This is something that requires that men obtain knowledge gradually at the same time as a gradual detachment occurs. It is a fact that the journalistic novel itself already deals with issues of reality when 
questioning its own limits, as we can see nowadays with productions and new use of language and narrative experiences. Productions that have been widening the concept, so that journalistic novels are no longer only seen as a Literature of Reality but as a Literature of Hyperreality, where various levels of realities are present.

Thinking on its educational context, in the sense of academic vision, in Brazil, Lima (2016) observed this complexity when he stated that:

\begin{abstract}
(...) an inherent complex epistemological characteristic, joining journalism - that is, the activity of communication of a mass developed by contemporary civilization to, in thesis, gather, investigate, ascertain and count social occurrences - to literature - in the sense of the narrative art of prose, in this case employed in the non-fiction territory -, necessarily confers it a conceptual situation, something hard to be framed by the linear criteria of classification and the understanding by the predominant theoretical lines of conservative and linear nature, in the academy, as well as by the professional practice in the editorial offices. The lack of an adequate classical frame - simplistic, in fact - makes it, for many, and ugly duckling, with no apparent well-developed identity. It is, deep down, a question of paradigms, of theoretical framing which govern, in the depths of its epistemological bases, the definitions, principles, procedures and the practice of each of these distinct models of journalism (Lima, 2016, p. 64).
\end{abstract}

As for ourselves, we have utilized, in the past years, the term Literature of Complexity (Castro, 2010) to define this form of writing that carries in itself various levels and is, for this reason, systemic. Systemic and complex because, in writing, it deals simultaneously with reality and the imaginary, truth and falsehood, fiction and nonfiction, in its relational, dialogical and knowledge producing characters.

Inside this order of ideas, it is also convenient to say that what is in discussion in Literary Journalism is the very notion of information, which amplifies its specter, ceasing to be mathematical (the maximum information in minimum space) to become multifocal and complex (multiple possibilities: diversity in the unity and economy of information allied to the beauty of expression). To be understood and developed through this perspective, Literary Journalism faces some limitations. First, the Schools of Communication today do not prepare students for narrative multiplicity, but for the sameness of lead (which, we must say, also has a stylistic beauty). Secondly, the teachers themselves would not know how to advance beyond the lead 
technique because they were taught, during various years, in this manner, transporting this method into the classrooms. When they only teach the lead technique (and the fault does not lie in them, but in the deficiency of Communication teaching in Brazil), other narrative techniques are left behind. Thirdly, it is not in the interest of many of the newspapers to leave, be it short or long term, the lead, for three reasons: 1. There is the myth that the reader does not have the time to read the paper; 2 . There is the myth that the reader only buys the paper to rapidly gather information on what he/she wants, and 3. For this reason there is a myth that says that Literary Journalism is something akin to beating around the bush or, in the journalistic jargon, akin to a filler, and since the journalism company has to save paper, has no advertisers and does not want to invest in talented professionals, Literary Journalism is, at times, viewed with disdain. Maybe it is time to pay more attention to the reader's point of view and stop legitimizing false discourses about the press. Can it really be that objectivity, salary and space and time issues justify the narrative problems we face in contemporary journalism?

If thought through the news story bias, we can say that Literary Journalism has two main objectives: 1 . To deepen or upright the journalistic text through literary resources and stylistic freedom, creating a diversity of narratives and narrators that, as we see it, only enriches reading and the newspaper. In Brazil, for example, a style still sparsely utilized is that of the "Authorial Journalism", or first person journalism, similar to what literature and cinema already does in a rich and healthy manner. 2 . To bet on the pleasure of writing and of text.

If thought through the news article bias, Literary Journalism is apparently not possible, but that is another myth. In twenty or thirty centimeters of text, the potency level of the word only rises when full of aesthetic force, in a brilliant prose, with human warmth, creativity, no opacity and plenty of emotion.

There are those who say that Journalism and Literature are two different cosmovisions and that this discussion is like trying to mix water and oil. There is no reason why one can't reach out to the resources and cosmovisions of the other as a means of investigation, observation and of unveiling men and the world. There is no reason not to critically evaluate the frontiers that separate Journalism from Literature, when Alceu de Amoroso Lima (1990) himself wrote that 
Journalism is but one more genre in Literature. And, we might add, what a beautiful genre! Here, the criticism made on the frontier between these two areas is a cause we believe is worthy of both Journalism and Literature: the cause of pleasures and challenges. A few years ago we wrote:

\begin{abstract}
Pleasure is in being able to make adjacent and convergent knowledge converse, and also in succinctly promoting an archeology of journalism in the face of literature. The challenges are many and of various orders. From the criticism of the internal structure of the Communication departments to the forms of comprehension and interpretation of reality. Here we will notably stand by the second aspect. Interpreters by nature, journalists and writers are also interpreted by their interpretation techniques. This means that interpretation also demands a watchful and rigorous self-comprehension of these techniques and these interpreters (Castro, 2002, p. 10).
\end{abstract}

These are not new forms of opposition to the different social roles of the journalist and the writer. Both work with the word, with the world, with subjectivity and objectivity. It is up to each of them to choose the focal point where they prefer to narrate and what they have to narrate. Obviously, if every journalist could stay at home writing whatever they wanted, it would be ideal, but not possible since he has to narrate what they are told to narrate or what the world gives them - it could at least be with a little creativity, emotion and sensibility. We will return to this topic further ahead, but make it clear from the start that creativity, emotion and sensibility were stripped from journalistic texts with no means of defense; on the contrary, anything that remotely points in this direction is immediately tagged as "sensationalist". There is a necessity to find a dividing point between what is "sensationalism" and what is sensibility, emotion, subtlety, sweetness, delicateness, tenderness, poetry. Did the choice for objectivity cost us so much? The dividing point between making sensationalist journalism and writing with emotion is, and in this alone, in the ethical issue.

For this and other reasons we all know that contemporary journalism needs reforming. Certainly one of the operators of this reform will be the capacity of oriented paradigmatic opening in the sense of incorporating various horizons, cross referencing discourses, proposals and objectives.

Maybe part of this reform will be looking back at the past and its lessons. If we do this, we will see that not all is as modern as we think and the ancient people already had a form of Literary 
Journalism. Ancient historians and chroniclers, such as Herodotus (485-420 B.C.) and Pliny the Elder (23-79 A.D.), managed to unite various genres in a practice which was quite similar to what we started calling Journalism, in which there was not only narratives about common occurrences, but the most diverse literature, such as the fantastic, the lyric, the adventurous, the gnomic, the critical, among others (Castro, 2010).

Literary Journalism is, from our point of view, the discursive capacity to encompass, in a rich and diverse narrative, existence's hyper complexity, because it contains in itself a cultural infinity which encompasses science, history, religion, ethics and politics. It is the path to comprehend human genre, a mix of information and knowledge, capable of transforming and orienting this same knowledge into sapience.

\section{Literary Journalism as a subject of transdisciplinary knowledge}

To understand Literary Journalism as a transdisciplinary knowledge it is necessary to first understand that transdisciplinarity does not oppose the disciplinary approach, but complements it, extracting from it new data, resulting from the confrontation of the disciplines it articulates, opening them to what binds and surpasses them. The knowledge in Literary Journalism is about, in a first instance, the discipline necessary to an apprentice journalist, for it allows him/her to develop creative, imaginative and narrative competencies. In a second instance, this knowledge also teaches the apprentice about social and human sciences, as well as physical and biological sciences, which he/she requires to understand that what is captured from an empirically observable reality is not separate from the psychic and energetic processes that imagination is capable of generating in a complex universe of interconnected beings.

In so being, the force of creativity, intuition and sensible perception comes as a complement to the force of empirical observation and the exactness of registry and analysis of the collected data; and all these forces will have to be articulated and representable through language. In a more palpable application, while narrating a fact, the journalist may conform to the objective and dry data demanded by the lead, but may also aggregate to 
the narrative the inexact data of imagination which conducts the reader to other universes of possibility and of reading and analysis of reality. It is necessary then that the journalist have sufficient domain of his/her own text to make it clear to the reader what belongs to the registry of objective reality and what refers to the subjective order and the increased appreciation of reality in its various levels of complexity. Such competency is, in fact, object of the disciplinary knowledge of Literary Journalism which, located in the frontier between Journalism and Literature, opens a dialogue between the two areas in such a manner as to give the journalist the techniques and abilities which a literate or a writer must have in order to narrate, in the exact measure, that which needs to be narrated and described.

Article 2 of the Charter of the International Center for Transdisciplinary Research (CIRET) ${ }^{2}$, signed in 1997 in Locarno, Switzerland, mentions that "The recognition of the existence of different levels of reality governed by different types of logic is inherent with the transdisciplinary vision", making it necessary to have an education for the different levels of reality in all disciplinary areas of knowledge. That is, it is necessary to create a conscience that reality's domain does not end at the limit of science, or better put, that the frontier between one science and another, between one disciplinary domain and another, is foggy and indefinite, and that there are other realities that traverse all of them, forming common ground. "The profound meaning of the transdisciplinary non-fusional unification is impossible to comprehend if the notion of 'levels of reality' is not taken into account" (Nicolescu, 2009, p. 4). Further on, the transdisciplinary thinker continues:

By level of Reality, we designate a set of systems which are invariant under certain general laws: for example, quantum entities are subordinate to quantum laws, which depart radically from the laws of the macrophysical world. That is to say that two levels of Reality are different if, while passing from one to the other, there is a break in the applicable laws and a break in fundamental concepts (like, for example, causality) (Nicolescu, 2009, p.5).

Every journalist needs to know the difference between historic time and mythic time, between a realist narrative and a mythic narrative, between physical reality and imaginary reality. A literary teaching may give the future journalist knowledge of these 
different levels of reality, a teaching that presents itself as Literary Journalism. But it is the practice of writing and reading which will give him/her the competence to become a journalist writer, capable of transmitting to the reader, with confidence, a piece which not only accomplishes the goal of journalistic information, but also has a power of enchantment to generate in the reader sufficient interest and taste for journalistic writing.

The thematic and critical importance of the levels of reality may be learned through the studies of Literary Journalism themselves, as pointed out by Martinez (2016) when he catalogues, from Lima (1993), his "ten pillars of literary journalism": 1) Accuracy and precision; 2) Telling a story; 3) Humanization; 4) Comprehension; 5) Thematic universalization; 6) Personal style and authorship; 7) Immersion; 8) Symbolism; 9) Creativity and 10) Ethical responsibility. The researcher highlights the "immersion" as an aesthetic experience: "First the author dives into reality, lives intensely, with body and soul, the experience and lives of the characters. It is only afterwards that he distances himself, reflects upon the experience, allows emotions, intuitions and thoughts to settle. Then he writes" (Martinez, 2016, p. 48).

The nautical metaphor utilized by Lima ("immersion/dive"), in this example, does not exclude the other metaphor of reality, an aerial metaphor, referring to the overflight, when it is understood that the author "distances himself, reflects", and only "then" writes. The ideas of "diving" and overflight, as well as that of approximation and distancing of the author, correspond, in our opinion, to the problems of depth of the levels of perception of reality.

We have analyzed, in a study on the journalistic work of Gabriel Garcia Márquez (Dravet, 2013), how the author managed, in his journalistic texts, to "elevate fact to myth". This means that what is news, fact, involving people, times and places, become myths in the author's texts. The time, the people, the places and the events are real in the sense that they are material in physical life; but in the journalistic narrative of the author, seem to become mythic, creating a strong appeal to the act of reading and to the reception of the news itself:

The elevation of a journalistic text to the mythic level is a process which acts in three ways: 1) transforming the reality of a single fact into a reality of universal nature; 2) placing the reader face to face with the issue of reality and of the limits of reality; 3) permitting the reader to access new universes of possibilities as much in the level of experience as in the level of belief. In these three manners it is possible to create a kind of 
journalism that not only covers information, but also formation and knowledge (Dravet, 2013, p. 75).

Therefore, in the disciplinary perspective, Literary Journalism acts on the formation of the future journalist, showing the techniques and giving the instruments for the development of narrative competencies and abilities necessary to a livelier and more compelling journalism. From a transdisciplinary perspective, it should be able to awaken in any student/reader the sensible perception and rational comprehension that, in reading the newspaper, levels of reality merge and distinguish themselves, and that these levels operate not only in the narrative of daily life undertaken by the newspaper, but also in the reality in which the biologist, the physicist, the mathematician, the astronomer, the engineer, the geographer, the sociologist, the psychologist etc. observe and analyze narratives in their respective professional work.

According to Michel Maffesoli, in the 21 st century there is no ideological, religious, institutional or political guarantee that allows us to establish our models of society in firm and logical bases. The thinker says that "social life, in its completeness, is immersed in an aesthetic aura; it is composed first and foremost, and increasingly, of emotions, feelings and shared affections" (Maffesoli, 1998, p. 115). For this reason, Literary Journalism, as a sensible narrative of reality, shows itself as an alternative to the presentation of social life (and not representation) which may bring in its formats and genres, more or less shortened and condensed, more or less rapid and objective, making it possible to fit, in the thirty centimeters of a news piece, in the two hundred fifty pages of a reportage book, or in one hundred lines of a news blog, the complexity of social life with its facts, events, occurrences and also emotions, feelings and shared affections.

\section{The journalistic and literary knowledge of João Guimarães Rosa: the interview portrait of Vaqueiro Mariano}

We consider two aspects as the journalistic and literary knowledge of João Guimarães Rosa: 1) The communicationalnarrative knowledge present in the art of conversing, the notion of "entremeios" 
with each other as well as the use of language, and 2) The knowledge gathered and collected in the proximity practice with the news field itself, for we know that Rosa dedicated himself to the exploration of techniques and interactive foundations regarding Journalism in the construction of some of his stories.

We should also mention that Journalism was prominently present in Guimarães Rosa's life as a transdisciplinary knowledge. He knew how to reassess his readings of newspapers and his interaction with various journalists in a greater strategic and pedagogic plane. The open plane of this coexistence made him interact with various journalists, such as Álvaro Lins (1912-1970), Franklin de Oliveira (1916-2000) and Josué Montello (1917-2006). Besides these journalists, the writer from the State of Minas Gerais, also maintained sparse but close relations with important names of the brazilian's new world at that time, such as Pedro Bloch ${ }^{4}$ (1914-2004), José Carlos de Macedo Soares ${ }^{5}$ (1883-1968), Joel Silveira ${ }^{6}$ (1918-2007), Antonio Olinto $^{7}$ (1919-2009), Assis Chateaubriand ${ }^{8}$ (1892-1968) and João Neves da Fontoura ${ }^{9}$ (1887-1963). Therefore, Rosa's role in this environment was more about collecting information and diffusing knowledge than responsibilities befitting pragmatic and market obligations.

The writer observed the productive routines, the savoirfaire, the agendas and the fake and distorted news. Mindful of this reality, Rosa even followed attentively the news planted by the Nazi regime in the years he lived in Hamburg (1938-1942), as can be seen in "Diário de Guerra"10 - his notebook with notations about the daily life during the Second World War in Hamburg, Germany. In this cycle of interactions with journalists, newspapers, communication entrepreneurs and historical facts, Rosa constructed his own vision of communication as a circuit, connected to various terminals (knowledge), among which one of them was the press, of evidently encyclopedic character, as was the style of the writer, an intense cataloguer of all information with which he crossed.

His proximity, his interest and, mainly, his presence in the press is attested also by the volume of texts published by him in newspapers and supplements. Between 1947 and 1967, Guimarães Rosa published 122 texts in newspapers such as O Globo, Pulso, Correio da Manhã, O Jornal (RJ), O Cruzeiro, Manchete, Senhor, Letras e Artes (suplemento do jornal A Manhã), Diário de Minas (MG), Folha da Manhã (SP), O Estado de S. Paulo (SP) and Jornal de Letras $(R J)$. Afterwards, all these texts were incorporated to the following 
books: Primeiras estórias (1962) and Tutameia (Terceiras estórias) (1967), published in life; and Estas estórias (1969) and Ave, Palavra $(1970)^{11}$, post mortem editions.

We should highlight that one of the particularities of Rosa's literature is the presence of subjacent interviews, such as the one that composes the great background of the novel Grande Sertão: Veredas, and also is present in the tales of "Meu tio, o lauaretê" and "Entremeio: Com o vaqueiro Mariano".

In this kind of text, we see a "monologue inserted in a dialogical situation" (Schwarz cited by Bolle, 2004, p. 40). The quasi interview or the semi-structured interview is a technique widely utilized by Rosa for the silent exchange between the mediator and the listener and vice-versa. In the emblematic case of Grande Sertão Veredas, for example, the interlocutor of this exchange seeks to understand how and why a semi-literate rural man, ex-gunman, assimilated, learned and posed complex and sophisticated questions of philosophical and existential order. The interview appears here with the capacity to mediate testimony, with or without criticism and judgment, but before one's opening and hearing.

In the case of the interview with Vaqueiro Mariano, which Paulo Rónai calls, in the introductory note of Estas estórias, "interview portrait", may be the most eloquent example of Literary Journalism in the works of Guimarães Rosa, where techniques and interactive foundations of this type of narrative are evident in the construction of the story.

It is valid to question whether Rosa utilized elements of fiction in the construction of the cowboy character. But the presence of Literary Journalism is undeniable, regarding the combination of knowledge, techniques and styles of the journalistic narrative that emerge from real facts.

After more than 70 years after the matter, with no access to the primary sources of information, what we know of real data is that the character really existed and, years later, conceded an interview to weekly newspaper Flan ${ }^{12}$, newspaper that belonged to the group of Samuel Wainer, in which the character spoke about the time of more than one week he spent with Guimarães Rosa. The Firme farm, background for the news report, existed and hosted Rosa during his trip to the Pantanal in 1947. There, author and character spent time together, conversed and interacted. And in the end, the story went public, in three parts, through the 
pages of the newspaper Correio da Manhã, the most important of its time in Rio de Janeiro.

What draws attention to the "verification" results is the conjunction of the reality data with a sophisticated narrative, where selected vocabulary, style and musicality coexist. This conciliation between facts and literary text is already evident on the second paragraph of the journalistic profile.

His face, of frank making, very tanned, thin, took airs of sobriety, a little excessively, of a man of action put into a meditative job. But the large kind eyes watched each one of my gestures or movements, subsequently, showing a purpose to protect, a little curiosity and the minimum of automatic wariness (Rosa, 2015, p. 93).

Rosa suggests that the cowboy paid close attention to him, fact which the character confirms to the reporter from Flan. Mariano indicates the practice of journalistic verification techniques employed by Rosa, making questions and writing down the answers in a small notebook he carried.

\footnotetext{
- He left it, I picked it up, he quieted and would keep fiddling with a little notebook. He wanted to know all things: the name of the birds, of plants, the name of the cows. Wouldn't let go of the little notebook, not even during the rodeos. From time to time would stop the horse to ask things, pulled out the little notebook and wrote (Flan, 1953, edition 14, p. 36).
}

What is most curious in the interview given by Mariano to the weekly newspaper Flan is, however, the possibility of conflict between his declarations and passages from Rosa's writings. There are, in fact, coincidences between the cowboy's testimony and facts recounted in the text. Be that as it may, there are moments in which it is possible to glimpse a visible reworking by Rosa on the reality of the occurrence.

In a cross referencing exercise, it is possible to see Mariano's and Rosa's telling about a single episode: the milking of cows. Mariano says: “'Mister' Guimarães was funny... He woke me up every day at two in the morning to milk the cow, with him along. We would go and he held the bucket and asked to learn how to squeeze the udder. I let him do it. But he lacked the knack, oh my! And the cow would hide the milk..." (Flan, 1953, edition 14, p. 36).

In his final product, however, Guimarães Rosa writes: 
They bring Pombinha and Biela close to the fence, and bind their hind legs. Then come their jumping offspring. They tie them up. The milker squats. The little calf stops at a right angle, under the mother's neck, and, starving, licks her mouth. The man harvests the cow's udder: manipulates, agile fingers. A white thread shivers, hitting the bucket, running down. The smell of milk blossoms, like nausea. The calf struggles, its head emerges, searching (Rosa, 2015 , p. 108).

In another moment, Mariano tells the reporter that Rosa confided that he wanted to know the "soul of the cattle":

\begin{abstract}
The funniest thing in 'mister' Guimarães was when cows were mentioned in the conversation. One time he suddenly told me, in the middle of the field, 'Mariano', and paused, 'I only just wanted to penetrate the bovine's soul!' I said, 'what a weird thing, mister', and he went on, 'When I see the wet grass I only feel like grazing...' (Flan, 1953).
\end{abstract}

In the interview portrait, Rosa makes the following affirmation about Mariano: "I had the need to learn more, about the soul of the cattle, and instigated him to provide me with the facts, cases, scenes. Wrapped up in a poncho, his palms spread on the table cloth, like a stalking animal, he tried to comply" (Rosa, 2015 , p. 93).

A close friend of Rosa's, the writer Paulo Dantas reports that he had a conversation with Rosa about the cowboy Mariano. In one more evidence of Literary Journalism, Dantas refers to the text as "the most beautiful transfigured story written on the Pantanal" (Dantas, 1975, p. 21).

In the same account, Dantas remembers that Rosa considered Mariano's profile for an interview, which he planned to turn into a book. Which he in fact did, in 1952, by the hands of the poet Thiago de Mello, by the small publishing house called Hipocampo, from Niterói (RJ). To reinforce the real data in the work, Dantas remembers part of a dialogue in which Rosa mentions the "soul of the cattle" and refers to the text as a piece of journalism. "That cowboy still exists. He is my great friend. With him I learned much about the soul of the cattle. (...) I have been feeling the urge to transform that news story into a book. Enlarge everything, in a crescendo; my friend, Mariano, deserves it" (Rosa cited by Dantas, 1975, p. 22).

The relationship Rosa establishes with Mariano is one of frank, sincere, mutual, reciprocal learning, of open communicative 
exchange. Mariano is willing to talk about or teach him, under the light of an oil lamp, about the nature of animals. Rosa wants to learn more about the soul of the cattle. This learning implies understanding the "tranquil kind of strength" (Rosa, 2015, p. 94); "the slow meekness learned" (Rosa, 2015, p. 95); "the vastness where reality steals the fable" (Rosa, 2015, p. 95); that the "stories not only detach themselves from the narrator, but they conduct him; narrating is resisting" (Rosa, 2015, p. 98); "they teach how to approach infinity" (Rosa, 2015, p.113) and "about the impossible" (Rosa, 2015, p. 117) etc. In this tale, the capacity to search alterity for his self-education is typical of an attitude that breaks the disciplinary barriers. To learn about the soul of the cattle, he relies on the cowboy/teacher (Mariano). To speak about the human soul, diabolical, Rosa will rely, in turn, on the ex-gunman/teacher (Riobaldo).

What is to be remarked here is Rosa's evident flirting with Literary Journalism, stemming from the value the writer conferred to the merging of real elements and literary text. In a letter to his father, Florduardo Pinto Rosa, the writer confides his appreciation for using real facts to enrich his literary work.

\begin{abstract}
I am writing other books. I remember many interesting things, have many notes, and many other things I create or invent, by imagination. But an expression, a song or phrase, legitimate, original, with the force of truth and authenticity, which comes from the origin, is like a nugget of gold, with immense value. (...) But don't tell other people, so that I may use them first hand (Rosa, J. G. cited by Rosa, V. G., 2014).
\end{abstract}

The conclusion thus reached is the extraordinary apprehension of journalistic knowledge per se, by Rosa, with the practice of the "divestment exercise", as he defined his fortnightly collaboration to the medical journal Pulso: the search for the "just" word. In a letter addressed to Manuel Bandeira, Rosa precisely explains how this "divestment exercise" happens:

I start writing; a world of things, ideas, images, reminiscences come to my rescue. I write five, ten, fifteen pages. It is necessary to cut back to three. I start crossing out, start correcting. My wish is to go on correcting until the end of my life. But we must hand in the originals. And on the next day, restart something new (Rosa cited by Bandeira, 1966, p. 319). 
However, more than this, the lesson is the mastery with which Guimarães Rosa worked, with a highly polished language and, at the same time, simple, with the levels of language. The communicational and narrative knowledge present in the art of conversation, the notion of "entremeios" (ins and outs), dialogues and interviews the characters conduct among themselves make evident the various independent layers, but compose a greater narrative whole (Castro, 2010) of the work of literary journalist Rosa. Therefore, this brief exercise apprehended in the interview portrait of Vaqueiro Mariano and his counterinterview in the weekly newspaper Flan approximates itself to the intense multiple structure of narrative construction that Ítalo Calvino talks about in the essay Níveis de Realidade na Literatura (Levels of Reality in Literature): "I write that Homer tells that Ulysses says: I have listened to the song of the Sirens" (Calvino, 2006, p. 373).

\section{Final considerations}

The news report on Vaqueiro Mariano - which may be seen as the most eloquent case of Literary Journalism in the works of Guimarães Rosa at the same time as it presents a pedagogic roll of the relationship that is established between the two speakers - allows us to identify that the transdisciplinary character of Literary Journalism is present in two levels: 1) at the level of the communications dimension present in journalistic information itself; and 2) at the level of the cultural and complex dimension present in the literary arts. Communication and culture are two buildings, or dimensions, that reveal the complex character of the transdisciplinary perspective. When we call Literary Journalism "literature of complexity", we precisely want to access this multidimensional source of knowledge. They are dimensions that feed one another and that provide recurrences and recursiveness. From this perspective, Journalism should be integrated to the circuit of Communication, as Communication must be integrated to the circuit of Culture. What does this "circuit of Communication" means, present even in the writings of Guimarães Rosa? It is about perceiving not the unit, but the complexity; it is about thinking/ rethinking Journalism (and Communication) not based in a small 
amount of knowledge, but in its actual state of proliferation, dispersion and installments of knowledge.

This integration of Journalism to the transdisciplinary communication circuit roots the physical knowledge, and equally biological, in one culture, in one society, in one story and in one humanity. As signaled by the complexity thinker Edgar Morin, from this educational and communicational transdisciplinarity, "the possibility of communication among the sciences is created, and the transdisciplinary science is what may develop from these communications" (Morin, 1996, p. 139). Morin tries to consider "the conditions for the construction of this circuit, hence its "encyclopedic" character, seen as I put into pedagogic cycle (agkukliós paideia) these spheres which up to now did not communicate" (Morin, 1996, p. 139).

The transdisciplinarity points to a responsibility towards what we teach (and learn) that goes through: 1) an adoption of a critical conscience and 2) the need to elaborate a science from science. The adoption of a critical conscience is the perception that the researcher is surrounded by hypothesis, conjectures, errors, prognostics, predictions and mistakes. This conscience tends to always put into crisis (and under a critical angle) that which seems evident. The necessity of elaborating a science from science reveals how the knowledge collected and explored by human beings have become complex. For this, it is necessary to "know to know", to seek a knowledge which will triumph over prohibitions, taboos or whatever limits it. A science from science implies "living a polytheism of values" (Morin, 1996, p.123). Finally, teaching Journalism is teaching Communication, which implies the exit of hyperspecialization and the opening for communicational knowledge of conversation (mediated by interviews); the pleasure of ethnographic exploration inherent to the profession of the journalist; the capacity to stimulate debate and dialogue, always under the prism of intercultural, transcultural, interdisciplinary and transdisciplinary openness.

Translated by: Kelly Missae Miyano Sumi 
1 Supplementation is a neologism that implies the division of the newspaper into supplements. Supplements on Cities, Economy, Politics, Sports, Culture and so on successively, depending on the internal organization method of each newspaper.

2 Institutional document available in http://ciret-transdisciplinarity.org/chart.php. Accessed in 03/04/2018.

3 "Entremeios": things inside things and things between things. "Entremeio. Com o Vaqueiro Mariano" is a literary interview written in 1947, later published in a book, in 1952, and is presently in Estas Estórias (2015). "Entremeio" in the Michaelis dictionary (1998) is (1) "intermediate"; (2) "lace worked in a strip, between plain spaces"; (3) "area in the body of the cow between the buttocks and the back, behind the udder. Neste entremeio: in the meantime; meanwhile".

4 Pedro Bloch was a multifaceted intellectual: journalist, phoniatric specialist, composer, poet, playwright, and author of children's books. He wrote over one hundred books. He was cousin to Adolpho Bloch, communication businessman and owner of the Manchete magazine.

5 José Carlos de Macedo Soares was an influential Brazilian politician. Jurist, historian, was Minister of Justice, Internal Affairs and Foreign Affairs in the governments of Getúlio Vargas, Juscelino Kubitschek and Nereu Ramos. Member of the Brazilian Academy of Letters (ABL), president of the Society of Geography of Rio de Janeiro, president of the Historical and Geographical Institute (IHG) and of the Brazilian Institute of Geography and Statistics (IBGE). He was one of the organizers of the Moder Art Week in 1922. His family owned newspapers and radio stations in Rio de Janeiro.

6 Joel Magno Ribeiro da Silveira was an influential Brazilian columnist, writer and journalist. He worked in various newspapers and magazines. He was known for covering the events of the World War II in Europe as a correspondent for the Diários Associados. He is considered to be one of the founders of Brazilian literary journalism.

7 Antônio Olinto was a Brazilian cultural journalist and writer. 
His column on books and literary critique in the $O$ Globo was one of the most read in Brazil in the 60's. Guimarães Rosa collaborated with the column during eight months in 1961. The work of Antônio Olinto encompasses poetry, romance, essays, literary critiques, political analysis, children's literature and dictionaries.

8 Francisco de Assis Chateaubriand Bandeira de Mello was a journalist, patron, politician and businessman. Known as Chatô, he was one of the most powerful businessmen in communication in Brazil in the 40's and 60's. He was the founder of the Diários Associados, which encompassed a chain of newspapers and radio stations throughout the Brazilian territory. He was a member of the Brazilian Academy of Letters (ABL).

9 He was a lawyer, diplomat, politician, writer and journalist. He was Minister of Foreign Affairs twice in the governments of Getúlio Vargas and Eurico Gaspar Dutra. He was the Ambassador of Brazil in Portugal between the years of 1943 and 1945. He was a columnist in the $O$ Globo and a member of the Brazilian Academy of Letters (ABL).

10 The so called "Diário de Guerra" ("War Diary") of Rosa's was organized by Eneida Maria de Souza, Reinaldo Marques and George Otte, teachers of the Literary Studies Program at Universidade Federal de Minas Gerais (UFMG). The teachers established a textual organization, with explanatory notes, introduction and translation of German expressions collected from the press by JGR and pasted to his diary. The photocopied manuscript can be found at the Henriqueta Lisboa Archives, in the Acervo de Escritores Mineiros, at UFMG.

11 It is emblematic that before opting for the definitive title Ave, Palavra (Hail, Word), the writer - who sometimes incorporated the reporter character - thought of naming the piece ... Reportagens (...Reports). According to Paulo Rónai, other options were: "Azulejos Amarelos (Yellow Tiles), Conversas com Tempo (Conversations with Time), Sortidos e Retalhos (Assortments and Patches), Desconexões (Disconnections), Via e Viagens (Road and Travels), Contravazios (Counter-emptiness), Moxinifada (Jumble), Almanaque (Almanac), Poemas do Esporádico (Poetry of the Sporadic), Exercícios de Saudade (Exercises of Longing), MeiasEstórias (Half-Stories) and Oficina Aberta (Open Workshop)" (Rónai, 2009, p. 19). 
12 O Vaqueiro e o Ministro: o personagem fala sobre o autor. 14 de julho, 1953. Disponível em http://memoria.bn.br/docreader/ DocReader.aspx?bib=100331 \&pagfis $=470$

\section{| REFERENCES}

Bak, J. (2017). Rumo a uma definição de Jornalismo Literário internacional. Brazilian Journalism Research,13 (3), pp. 136-161. Doi: http://dx.doi.org/10.25200/BJR.v13n3.2017.1007

Bandeira, M. (1966). Andorinha, Andorinha. Rio de Janeiro: José Olympio Editora.

Bolle, W. (2004). Grande sertão: Br. São Paulo: Editora 34/Duas Cidades.

Calvino, I. (2006). Assunto encerrado: Discursos sobre literatura e sociedade. São Paulo: Companhia das Letras.

Castro, G. (2010). Jornalismo literário: Uma introdução. Brasília: Casa das Musas.

Castro, G., \& Galeno, A. (2002). (Eds.). Jornalismo e Literatura: A sedução da palavra. São Paulo: Escrituras.

Dravet, F. (2013). Por um jornalismo latino-americano realista, literário e mágico: uma leitura das crônicas de Gabriel García Márquez. Logos 38. Realidade Ficção, 20 (1), pp. 73-85. Doi: https:// doi.org/10.12957/logos.2013.77

Dantas, P. (1975). Sagarana emotiva: Cartas de J. Guimarães Rosa. São Paulo: Duas Cidades.

Flan (1953, 14 de julho). O Vaqueiro e o Ministro: o personagem fala sobre o autor. p. 36. Recuperado de http://memoria.bn.br/ docreader/DocReader.aspx?bib=100331 \&pagfis $=470$

Hartsock, J. (2016). Literary journalism and the aesthetics of experience. Amherst, Boston: University of Massachusetts Press.

Juarroz, R. (2000). Poesia y realidad. Valencia: Pre-Textos.

Lima, A. A. (1990). O Jornalismo como gênero literário. São Paulo: Com-Arte, Edusp.

Lima, E. P. (2016). O jornalismo literário e a academia no Brasil: fragmentos de uma história. Famecos, 23, pp. 63-80. Doi: http:// 
dx.doi.org/10.15448/1980-3729.2016.s.25024

Lima, E. P. (s.d). Registros breves para uma história futura. Retrieved from www.edvaldopereiralima.com.br/index.php/ jornalismo-literario/pos-graduacao/memoria-portal-abjl/152registros-breves-para-uma-historia-futura-do-jornalismo-literario

Maffesoli, M. (1998). Elogio da razão sensível. Trans. Albert Christophe Migueis Stuckenbruck. Petrópolis, RJ: Vozes.

Martinez, M. (2016). Jornalismo literário: Tradução e inovação. Florianópolis: Insular.

Martinez, M. (2017). Jornalismo Literário: revisão conceitual, história e novas perspectivas. Intercom Revista Brasileira de Ciências da Comunicação, 40 (3), pp. 21-36. Doi: http://dx.doi. org/10.1590/1809-5844201732.

Morin, E. (1996). Ciência com consciência. Trans. Maria A. Sampaio Dória. Rio de Janeiro: Bertrand Brasil.

Nicolescu, B. (2009). Contradição, lógica do terceiro incluído e níveis de realidade. In Ateliers sur la contradiction: Nouvelle force de développement en science et societé. École des Mines: SaintEtienne, pp. 19-21. Trans. CETRANS. Retrieved from www.emse.fr/ aslc2009

Rónai, P. (2009). Os prefácios de Tutameia. In. Rosa, J. G. Tutameia (Terceiras histórias). 9. ed. Rio de Janeiro: Nova Fronteira.

Rosa, J. G. (2015). Estas estórias. 7ª ed. Rio de Janeiro: Nova Fronteira.

Rosa, V. G. (2014). Relembramentos. Rio de Janeiro: Nova Fronteira.

Soares, I. (2017). At the intersection of risk: when literary journalism and sociology study urban problems by means of akin methodologies. Sociologia, Problemas e Práticas, 84, pp. 63-80. https://doi.org/10.7458/SPP2017843466 
Gustavo de Castro is a Doctor. Assistant teacher at the College of Communication / Universidade de Brasília (UnB), Brasília, Distrito Federal, Brazil. E-mail: gustavodecastro@unb.br

Conception and Elaboration of the Study. Interpretation of data. Redaction, editing and final revision.

Florence Dravet is a Doctor. Masters Professor in Communication at the Universidade Católica de Brasília (UCB), Brasília, Distrito Federal, Brazil. E-mail: florence@ucb.br

Conception and Elaboration of the Study. Interpretation of data. Redaction, editing and final revision.

Andrea Jubé is a Journalist and law graduate. Attending a Master's degree in the research area of Image, Sound and Writing, at the Post-Graduate Program in Communication of the Universidade de Brasília (UnB). E-mail: andreajubevianna@ gmail.com

Responsible for the research regarding Guimarães Rosa's involvement in Journalism.

Victor Cruzeiro is a Philosophy graduate. Master in the research area of Image, Sound and Writing at the Post-Graduate Program in Communication of the Universidade de Brasília (UnB). Email:victorlcruzeiro@gmail.com

Responsible for the research regarding Guimarães Rosa's involvement in Journalism 